of conveyor vary with the time. In the motors ordinarily used, causes of failure arise from the whipping of the shaft and from the ingress of stone dust at the bearings. In the motors described, the roller-bearing at the driving end and the ball-bearing at the opposite end are both constructed in dust-proof 'housings'. The diameter of the shaft of a Metropolitan-Vickers new 15-h.p. conveyor motor is 2.5 in. and the rotating part is practically indestructible. The progress made in mechanical haulage will greatly diminish the use of animals underground for haulage purposes.

\section{British High-Speed Aircraft}

ThE Aeronautical Research Committee has recently issued a résumé of the original scientific work done by various authorities in Great Britain upon the development of racing seaplanes, which has led finally to the winning outright of the Schneider Trophy and the breaking of the world's speed record during September 1931 (Reports and Memoranda, No. 1300. "Collected Reports on British High Speed Aircraft for the 1927 Schneider Trophy Contest", by W. L. Cowley. London: H.M. Stationery Office). This is a departure from the normal procedure of issuing information in disconnected reports and memoranda as it becomes available, which has the advantage that it becomes virtually a textbook upon its subject and saves the labour necessary in hunting up such information when issued in separate pamphlets. On the other hand, if it is necessary to wait for more than four years for the collection and collation of such information, the advantage of its more convenient method of issue is largely outweighed by the obsolescence of its material. The subject matter is divided into separate headings of research, specifications, design and construction, inspection and test, and operational. It deals in great detail with three machines that are widely different in characteristics regarded from the point of view of high speed flight. The monoplane versus biplane, and the air-cooled versus water-cooled engine controversy is thoroughly fought out with representative machines of each class. The most significant thing about the report is the agreement between scientific prediction and actual results, and the ability of scientific investigation to explain apparent phenomena arising during practical use of the aircraft.

\section{Nickel in Marine Engineering}

THE January issue of the Transactions of the Institute of Marine Engineers contains, as usual, a selection of important articles from the technical press, and a report of a paper on "Nickel and Nickel Alloys in Marine Engineering", read to the Institute by Mr. J. McNeil on Dec. 8. Of all the many uses to which nickel has been put aboard ship, none has proved more valuable than when alloyed with copper for condenser tubes. For a very long period, the deterioration of brass condenser tubes, with its accompanying trouble through leakage of sea water, has been a very serious problem, especially in ships fitted with water-tube boilers, but it appears to have been solved at last by the use of an alloy of 70 per cent copper and 30 per cent nickel for the tubes. Alloyed with both ferrous or non-ferrous metals, nickel is used for steam turbine blades and nozzles, high-pressure steam valves and fittings, propellers, pistons and liners of Diesel engines, reduction gear wheels, and even crankshafts. Recently a process has been evolved in which nickel can be deposited in thick layers and thus worn parts built up. There is remarkable adhesion between steel and deposited nickel, and the resistance to shear of a thick ring of nickel deposited on steel is stated to be practically that of the metal itself.

\section{Arctic Exploration}

MUCH activity in polar exploration during the last year, particularly in Greenland and Northern Land and adjacent islands, is noted in the Polar Record for January. When Nansen crossed Greenland in 1888, the journey was considered to be difficult and adventurous. Since that date several other crossings have been made, but no period has been so fruitful in the exploration of the ice sheet as 1930 and 1931 . During that time, two observatories have been instituted and used for longer or shorter periods on the ice, including the German station of the Wegener expedition in the centre; three new crossings of the ice-sheet have been made, including one across the greatest width; and for the first time, echo measurements of the thickness of the ice have been taken. It is also noted that Soviet explorers from the station on the Kamenev Islands to the west of Northern Land, in long sledge journeys, have filled in the western coasts of that land and determined its northern extremity in lat. $83^{\circ} 16^{\prime} \mathrm{N}$., long. $95^{\circ} 37^{\prime} \mathrm{E}$., thus finishing the last piece of pioneer work that the arctic regions offered. Details of these and various other polar explorations are given in the journal.

\section{The Malabar District of India}

A series of articles on the Malabar district of India is published in an enlarged number of the Journal of the Madras Geographical Association (Oct. 1931-Jan. 1932). These papers were read at a conference of the Association held at Palghat in May 1931. They cover the geology, meteorology, botany, and agriculture of the district, and are illustrated by various maps. Following these there are other papers dealing with modern and ancient trade, trade routes, and urban centres. A particularly interesting paper treats of Roman trade centres on the Malabar coast. There are also notes on the place names. The volume is a useful contribution to the study of India, and is chiefly the work of Indian teachers.

\section{Tours in the U.S.S.R.}

IN 1931 the Society for Cultural Relations arranged two conducted tours to demonstrate present activities in science and medicine in the U.S.S.R. Similar tours, each lasting about a month, are being organised this year between July 15 and Sept. 15. It is hoped to arrange parties for physicists, biologists, medical men, and others, each party being limited to about twenty persons. Travelling arrangements will be made by Intourist, Ltd., Bush House, Aldwych, W.C.2, and

$$
\text { No. } 3257 \text {, VoL. 129] }
$$


competent guides and interpreters will be provided by "Voks ", the Soviet organisation for cultural relations with foreign countries. Full particulars can be obtained from the Society for Cultural Relations, 1 Montague Street, London, W.C.1.

\section{Royal Institute of Public Health}

THE annual Congress of the Royal Institute of Public Health will be held in Belfast on May 10-15, under the presidency of the Marquess of Londonderry. The Congress will be divided into the following Sections: I., State Medicine and Municipal Hygiene; II., Industrial Hygiene; III., Women and Children and the Public Health ; IV., Tuberculosis ; V., Pathology, Bacteriology, and Biochemistry. The inaugural meeting will be held in the Great Hall of Queen's University, at 11 A.M. on May 10, when the presidential address will be delivered. Several general excursions have been arranged, besides sectional visits to hospitals, sanatoria, etc., and certain institutions, centres, and works will be open for inspection. Further information can be obtained on application to the Secretary, Royal Institute of Public Health, 37 Russell Square, London, W.C.1.

\section{Anti-Malarial Measures}

Sir Malcolm Watson stated at a meeting held in January of the Industrial Anti-Malarial Advisory Committee of the Ross Institute for Tropical Diseases that while Paris green has a place in malaria control, it is not a substitute for oiling surface waters that breed mosquitoes, for the female can safely lay its eggs in water treated with Paris green, but is killed by water that has been oiled. The nature of the crude oil forming the basis of anti-malarial oiling mixtures has an important bearing on efficiency, and Dr. Ramsay, in association with the Burma Shell Group, has completed researches upon the oils best suited for such mixtures.

\section{Joint Archæological Expedition to Antioch}

Arrangements have been made, we learn from Science Service, Washington, D.C., between Princeton University, New Jersey, and the Musée National of France, the Baltimore Museum of Art, and the Worcester Art Museum, for a joint expedition of excavation at Antioch. A five-year programme of excavation has been arranged. Prof. George W. Elderkin, of Princeton, is leaving immediately for Antioch to initiate the work. It is expected that it will be possible to excavate this ancient city without any disturbance of existing buildings.

\section{Announcements}

$W_{E}$ much regret to announce the death, on March 26 , at the age of seventy-seven years, of the Right Hon. Sir Horace Plunkett, K.C.V.O., F.R.S., first vice-president of the Department of Agriculture and Technical Instruction for Ireland and a pioneer in the organisation and development of Irish agriculture.

AT the March meeting of the Council of the Institute of Actuaries, Mr. W. Palin Elderton was elected president to succeed Mr. H. M. Trouncer, whose term of office expires in June.
Mr. Aldous Huxuey will deliver the Huxley Memorial Lecture at the Imperial College of Science and Technology, South Kensington, London, S.W.7, on May 4, at 5.30 Р.м. The subject of the lecture will be "Huxley as a Literary Man".

Aт the annual business meeting of the Royal Philosophical Society of Glasgow, held on March 23, the following officers were elected: Vice-President, Dr. Henry L. G. Leask; Hon. Librarian, Dr. James Knight ; Hon. Treasurer, Sir John Mann ; Secretary, Mr. John A. Buyers; Members of Council, Mr. John P. Heslin, Miss M. A. Hannan Watson, and Mr. George B. Wishart.

LoRD WAKEFIELD has given a sum of $£ 25,000$, spread over seven years, as a contribution to the Imperial Institute. The Institute is financed by annual grants from the Treasury, the Dominions, India, and the Colonies, and was faced with the prospect of curtailment of its activities, owing to temporary reduction of some of its supporting grants. It is hoped that Lord Wakefield's gift will enable the Imperial Institute to tide over the period of difficulty.

A course of three public lectures on "The Rôle of Statistical Method in Industrial Standardisation" will be given by Dr. W. A. Shewhart at University College, Gower Street, London, W.C.1, on May 3, 5, and 6 , at 5.30 P.M. Dr. Shewhart is a member of the technical staff of the Bell Telephone Laboratories, New York, and in these lectures an attempt will be made to outline the present status of the applications of modern statistics. A syllabus of the lectures may be obtained on application to the Academic Registrar, University of London, South Kensington, London, S.W.7.

Applications are invited for the following appointments, on or before the dates mentioned :-A public librarian under the Colwyn Bay Urban District Council-The Clerk to the Urban District Council, Council Offices, Colwyn Bay (April 14). An assistant curator in the Royal Botanic Gardens, Kew, in charge of the Decorative Department-The Secretary, Ministry of Agriculture and Fisheries, 10 Whitehall Place, S.W.1 (April 15). A mathematical master at the Royal Naval College, Dartmouth-The Headmaster, Royal Naval College, Dartmouth (April 18). A professor of philosophy at Armstrong College-The Registrar, Armstrong College, Newcastle-upon-Tyne (April 20). An assistant in the Natural History Department of the University of Aberdeen-The Secretary, University, Aberdeen (April 20). A reader in chemical engineering at the Imperial College (Royal College of Science)-The Academic Registrar, University of London, South Kensington, S.W.7 (April 22). A professor of zoology at Armstrong College and director of the Dove Marine Laboratory-The Registrar, Armstrong College, Newcastle-upon-Tyne (April 23). A whole-time radiologist at the Johannesburg Hospital-The Superintendent, Johannesburg Hospital, Johannesburg, South Africa (May 25). A male laboratory assistant at the Government Experimental Station, Porton-The Commandant, Experimental Station, Porton, near Salisbury. 